\title{
PERNYATAAN KONSUMEN LEWAT INTERNET (eWOM), HARGA, DAN KUALITAS PELAYANAN TERHADAP KEPUTUSAN PEMBELIAN
}

\author{
Redy Eko Hari Suprapto \\ Fakultas Ekonomi dan Bisnis, Universitas Wijaya Kusuma Surabaya \\ redy_ehs@yahoo.com
}

\begin{abstract}
This research aims to investigate (1) the effect of electronic word of mouth to Blibli.com Ecommerce purchase decision, (2) the effect of price to Blibli.com E-commerce purchase decision, (3) the effect of service quality to Blibli.com E-commerce purchase decision. This research is quantitative research with causal associative design. Research population is all people have ever bought products or goods on E-commerce Blibli.com in Surabaya. Sample in this research amount to 100 people who ever bought products or goods on E-commerce Blibli.com in Surabaya. The data collection technique was used questionnaire that has been tested for validity and reliability. Data analysis technique in this research was used multiple regression. The result of this research showed that (1) electronic word of mouth has a significant positive effect to Blibli.com E-commerce purchase decision, (2) price has a significant positive effect to Blibli.com E-commerce purchase decision, (3) service quality has a significant positive effect to Blibli.com E-commerce purchase decision, and (4) electronic word of mouth, price, and service quality has a significant positive effect to Blibli.com E-commerce purchase decision.
\end{abstract}

Key Words: electronic word of mouth; price; service quality; purchase decision

\begin{abstract}
ABSTRAK
Penelitian ini bertujuan untuk mengetahui: (1) komunkasi lewat internet platform terhadap keputusan pembelian pada konsumen e-commerce Blibli.com, (2) harga terhadap keputusan pembelian pada konsumen e-commerce Blibli.com, (3) kualitas pelayanan terhadap keputusan pembelian pada konsumen e-commerce blibli.com. Penelitian ini merupakan penelitian kuantitatif dengan rancangan asosiatif kasual. Populasi dalam penelitian ini adalah seluruh orang yang pernah membeli produk atau barang pada E-commerce Blibli.com di Surabaya. Respondennya adalah konsumen yang pernah membeli produk atau barang pada E-commerce Blibli.com di Surabaya yang berjumlah 100 orang. Data yang dikumpulkan dengan menggunakan kuesioner. Teknik analisis data menggunakan analisis regresi berganda. Hasil penelitian menunjukkan bahwa (1) Komunikasi lewat internet platform berpengaruh terhadap keputusan pembelian pada konsumen e-commerce Blibli.com, (2) harga berpengaruh terhadap keputusan pembelian pada konsumen e-commerce Blibli.com, (3) kualitas pelayanan berpengaruh terhadap keputusan pembelian pada konsumen $e$-commerce Blibli.com.
\end{abstract}

Kata Kunci: komunikasi lewat internet platform; harga; kualitas produk; keputusan pembelian

\section{PENDAHULUAN}

Dimasa pandemi seperti sekarang ini dalam melakukan usaha melalui kegiatan formal akan sangatlah sulit. Strategi pemasaran melalui internet merupakan suatu trobosan dalam mencari konsumen baru dan mempertahankan pelanggan lama dalam rangka meningkatkan volume penjualan.

Cara dalam mempertahankan konsumen lama maupun menciptakan konsumen baru misalnya meningkatkan kualitas kualitas produk atau menghasilkan produk dengan inovasi baru. Internet merupakan suatu cara untuk mempermudah mengenal suatu produk dan kunsumen bisa bertahan terhadap suatu produk (Rahmadhani, 2011).

Sarana komunikasi dalam menghubungkan antara satu orang dengan orang lain pasa saat ini adalah melalui media internet karena jangkauannya yang sangat luas, biaya transaksi, biaya agensi, interaktif, fleksibel dan mudah serta mempunyai kemampuan utnuk mendistribudikan pengetahuan secara cetap dan tepat. (Laudon dan Laudon, 2007). Berdasarkan Survey yang dilakukan APJII (Asosiasi Penyelenggara Jasa Internet Indonesia) tingkat pengguna internet di 
indonesia dari tahun ke tahun selalu mengalami peningkatan.

E-commerce merupakan tren yang sedang berkembang dalam menciptakan peluang baru bagi perusahaan dan konsumen dengan jumlah pendapatannya yang selalu meningkat. Strategi bisnis sebagai saluran distribusi yang seharusnya digunakan perusahaan saat ini yaitu media $e$ Commerce.

Menurut Sutedja (2007) Media elektronik dengan menggunakan e-commerce merupakan menset dinamis tehnologi, aplikasi dan proses bisnis menghubungkan antara perusahaan, konsumen dan kelompok tertentu melalui transaksi elektronik, perdagangan berbagai barang dan jasa, pelayanan serta pemberian informasi. E-Commerce yang ada di Indonesia antara lain yaitu Blibli.com, Tokopedia, Bukalapak, Shopee, Elevenia dan lainlain. Sehingga perusahaan hanya perlu menyediakan foto barang dagangan dan upload gambar, mencantumkan harga dan deskripsi lain mengenai barang dagangannya. Selanjutnya pihak penjual akan diberikan notifikasi oleh sistem dari e-commerce tersebut kepada konsumen.

Blibli.com merupakan situs jual beli online yang didirikan oleh PT. Global Digital Niaga (GDN). PT. Global Digital Niaga (GDN) merupakan anak perusahaan dari Djarum yang bergerak di bidang digital.

Dengan kemudahan dan kecanggihan internet, promosi-promosi yang dilakukan oleh perusahaan agar produknya dapat tersampaikan dan dilihat banyak masyarakat dapat dilakukan dengan komunikasi dalam internet platform yang tidak secara langsung bertatap muka dengan calon pembeli atau bisa disebut dengan electronic word of mouth (eWoM).

Komunikasi pemasaraan saat ini merupakan komunikasi pemasaran yang modern yang memudahkan konsumen untuk mendapatkan informasi dan membandingkan beberapa produk serupa sebelum mereka melakukan suatu pembelian. Dengan adanya informasi yang didapatkan di internet, konsumen dapat mengenal lebih dalam mengenai produk da perusahaan sehingga konsumen mampu melakukan pengambilan keputusan pembelian yang tepat.

Electronic word of mouth (eWoM) adalah sebuah pernyataan positif atau negatif yang terbentuk dari adanya opini para konsumen, baik para calon maupun mantan konsumen dari sebuah produk yang dapat di akses oleh khalayak luas di dunia maya (Henning-Thurau, 2004). Dalam prosesnya $e W o M$ dinilai akan lebih efektif karena diterapkan didunia maya yang Penyebaran informasinya yang lebih efektif dapat dengan mudah didapatkan oleh semua pengguna media sosial didunia maya yaitu dengan menggunakan electronic word of mount (eWoM).

eWoM merupakan media yang dapat diterima secara luas oleh khalayak dan dijadikan bahan pertimbangan dalam pengambilan keputusan dalam pembelian barang atau jasa. Selain itu sebagai konsep promosi lama yang diterapkan didalam dunia digital yang berbasis internet, Salah satu karakteristik eWoM adalah secara positif dapat mempengaruhi konsumen dalam proses pengambilan keputusannya. (Heninig Thurau. 2004)

Konsumen dengan sukarela menyebarkan suatu berita positif mengenai sebuah produk atau jasa merupakan tugas para pelaku usaha untuk dapat meningkatkan kinerja dan strategi usahanya. Yang pada akhirnya dapat meningkatkan penyebaran tanggapan positif pada eWoM di media sosial. Sehingga eWoM sebagai salah satu faktor penting yang membuat sebuah layanan yang dapat dipromosikan baik oleh perusahaan itu sendiri atau dari para konsumen mereka sendiri secara efisien.

Komunikasi $e W o M$ dapat dilakukan dengan memanfaatkan media sosial lainnya misalnya Instagram, Facebook, Blog, video, dan forum berbasis elektronik lainnya. Menurut Bashar (2012) media sosial memberikan informasi serta mempengaruhi keputusan pembelian dan lebih percaya terhadap opini rekan atau pihak lain daripada strategi pemasaran dari perusahaan dalam memutuskan pembelian.

Kemajuan teknologi komunikasi melalui internet dapat mendorong kemajuan bisnis membuat beberapa konsumen menjadi lebih sensitif terhadap harga. Perusahaan sebagai produsen dalam menawarkan produknya berusaha memberikan harga jual yang terjangkau. Dilakukan demi menarik konsumen baru maupun dalam upaya mempertahankan konsumen loyal (Kotler, 2009). Harga sebagai salah satu unsur dipertimbangkan oleh konsumen sebelum membeli suatu produk. Apalagi memasuki era internet, pengguna semakin kritis sebelum membeli karena mudahnya mencari informasi produk termasuk harga. Harga yang diharapkan oleh konsumen berbeda-beda. Sebagian rela membayar lebih demi kualitas yang diharapkan, dan sebagian ingin membayar lebih murah walaupin risiko kualitas kurang diharapkan.

Menurut Kotler \& Amstrong (2012) harga adalah jumlah dari nilai yang ditukar konsumen atas manfaat-manfaat karena memiliki atau 
menggunakan produk atau jasa. Penelitian yang disusun oleh Yitzhak, Willem (2015) yang menyatakan bahwa harga berpengaruh positif dan signifikan terhadap Keputusan Pembelian produk produk Smartphone Samsung.

Faktor penting lainnya yang mendorong kepuasan dalam keputusan pembelian adalah kualitas layanan. Kualitas pelayanan adalah suatu unsur paling penting yang harus diperhatikan oleh perusahaan, karena kepuasan dan keputusan pembelian pada pelanggan sangat dipengaruhi oleh kualitas layanan yang baik (Qin \& Prybutok, 2009). Sedangkan menurut Sutedja (2007). Pelayanan merupakan sebuah kegiatan atau keuntungan yang dapat ditawarkan oleh satu pihak kepada pihak lain yang meliputi kecepatan melayani, kenyamanan yang diberikan, kemudahan lokasi, harga wajar dan bersaing. Karena konsumen merupakan target utama dalam menjual produk dan sangat mempengaruhi hidup perusahaan. Tujuan penelitian ini untuk mengetahui (1) komunkasi lewat internet platform terhadap keputusan pembelian pada konsumen $e$ commerce Blibli.com, (2) harga terhadap keputusan pembelian pada konsumen e-commerce Blibli.com, (3) kualitas pelayanan terhadap keputusan pembelian pada konsumen e-commerce Blibli.com. Diharapkan sebagai masukan dalam melakukan kegaiatan operasional dengan menggunakan e-commerce selalu memperhatikan pernyataan konsumen lewat internet (eWOM), harga dan kualitas pelayanan.

\section{METODE PENELITIAN \\ Populasi dan Sampel \\ Populasi}

Definisi populasi menurut Sugiyono (2004) "dalam penelitian kuantitatif, populasi yang terdiri dari obyek atau subyek yang mempunya kualitas dan kerakteristik tertentu yang diterapkan peneliti untuk dipelajari dan kemudian diambil suatu kesimpulan". Satuan atau individu ini disebut unit analisa. Populasi yang digunakan dalam penelitian ini adalah konsumen e-commerce Blibli.com di Surabaya.

\section{Sampel}

Sampel dalam penelitian ini adalah konsumen yang pernah membeli produk atau barang pada $e$ commerce Blibli.com di Surabaya yang berjumlah 100 orang.

Adapun pengambilan sampel menggunakan teknik accidental sampling, yaitu pengambilan sampel di tempat kejadian dimana obyek penelitian berada yaitu di Surabaya. Dalam penelitian ini jumlah populasi konsumen Blibli.com tidak diketahui secara pasti, karena populasi yang diambil berukuran besar, maka rumus yang digunakan yaitu (Widyanto,2008):

$$
n=\frac{\mathrm{Z}^{2}}{4(M O E)^{2}}
$$

Keterangan:

n : Ukuran sampel

Z : Skor pada tingkat signifikan tertentu (derajat keyakinan ditentukan 95\%) maka $\mathrm{Z}=1,96$

Moe : Margin of Error, tingkat kesalahan maksimum adalah $10 \%$

Sesuai dengan rumus diatas maka diperoleh perhitungan sebagai berikut:

$$
\begin{aligned}
n & =\frac{(1,96)^{2}}{4(0,1)^{2}} \\
& =96,4=97 \text { atau dibulatkan menjadi } 100
\end{aligned}
$$

Dari hasil perhitungan diatas maka dapat diperoleh jumlah sampel yang diteliti yaitu 100 responden.

\section{Identifikasi Variabel}

Berdasarkan hipotesis, maka variabel-variabel yang akan diteliti:

Variabel independen:

1. Pernyataan konsumen lewat internet (electronic word of mouth $\left(\mathrm{X}_{1}\right)$,

2. Harga $\left(\mathrm{X}_{2}\right)$,

3. Kualitas pelayanan $\left(\mathrm{X}_{3}\right)$

Variabel dependen: Keputusan pembelian (Y)

\section{Metode Pengumpulan Data}

Dalam penelitian ini melakukan pengumpulan data, menggunakan kuesioner. Metode kuesioner yaitu metode pengumpulan data dengan cara mengajukan pertanyaan secara tertulis yang telah disusun secara sistematik untuk memberikan keterangan kepada penulis secara benar. (Sugiyono, 2009). Dalam kuesioner ini menggunakan skala likert (skala 5 poin).

Adapun skala nilai yang digunakan adala skala likert. Skala likert digunakan untuk mengukur sikap, pendapat dan presepsi seseorang atau sekelompok orang tentang fenomena sosial. Skor atas pilihan jawaban untuk kuesioner yang diajukan untuk pernyataan positif adalah sebagai berikut: Sangat Setuju (SS) dengan skor 5, Setuju 
dengan skor4, Netral (N) dengan skor 3, Tidak Setuju (TS) dengan skor 2 dan Sangat Tidak Setuju (STS) dengan skor 1 (Sugiyono, 2004).

\section{Teknik Analisis Data}

Terdapat beberapa tahapan dalam menganalisis data dalam penelitian ini. Tahapan dasar tersebut diantaranya ialah:

1. Proses editing

Melakukan edit terhadap data yang telah terkumpul dari hasil dilapangan. Dalam tahapan ini memilih data yang perlu dan membuang data yang dianggap tidak perlu.

2. Proses skoring

Data kualitatif diubah menjadi angka dengan mengkasifikasikan jawaban sesuai kuesioner, selanjutnya adalah menentukan skor atas jawaban responden sesuai anggapan responden.

3. Tabulasi

Hal ini bertujuan untuk memudahkan dalam membaca hasil dengan jelas. Setelah proses tabulasi selesai, data dapat diolah dengan alat SPSS.

\section{Metode Analisis Data}

\section{Uji Instrumen}

Kuesioner dalam penelitian ini memiliki sifat abstrak yaitu pernyataan yang tidak menjelaskan nominal pasti suatu variabel. Sesuatu yang abstrak jika diukur dengan beberapa pernyataan akan lebih relevan dibandingkan hanya dengan satu pertanyaan saja. Untuk itu digunakan uji validitas dan reabilitas untuk menghasilkan konstruk dengan item pernyataan yang tepat.

\section{Uji Validitas}

Menurut Ghozali (2002), Uji Validitas yaitu untuk mengukur sah (valid) dan tidaknya kuesioner dalam suatu penelitian dengan taraf signifikansi sebesar 0,05 .

Uji Reliabilitas

Uji reliabilitas dapat dibuktikan keandala-nya jika dalam beberapa kali pengukuran, hasil pengukuran yang dilakukan pada kelompok subjek tidak berubah atau konsisten. Ketentuan dalam uji reliabilitas ini adalah apabila nilai Cronbach's Alpha $<0,7$ berarti kuesioner tidak reliabel namun jika nilai Cronbach's Alpha $>0,7$ berarti kuesioner reliabel.

\section{Uji Asumsi Klasik}

Model regresi berganda dapat disebut juga sebagai model yang baik, jika model tersebut memenuhi asumsi normalitas data yang terbatas dari asumsi klasik statistik, baik itu normalitas, multikolinearitas, dan heterokedastisitas (Bhuno, 2005).

\section{Uji Normalitas}

Menggunakan uji normal probability plot dan dasar pengambilan keputusan untuk uji normalitas data adalah:

1. Jika data menyebar di sekitar garis diagonal dan mengikuti arah garis diagonal atau grafik histogramnya menunjukkan distribusi normal, maka model regresi memenuhi asumsi normalitas.

2. Jika data menyebar jauh dari diagonal dan atau tidak mengikuti arah garis diagonal atau grafik histogramnya tidak menunjukkan distribusi normal, maka model regresi tidak memenuhi asumsi normalitas.

\section{Uji Multikolinearitas}

Untuk mengaji model regresi yang ditemukan adanya korelasi antar variabel bebas dimana model regresi yang baik tidak terjadi korelasi di antara variabel bebas (Ghozali, 2001). Mendeteksi adanya multikolinearitas adalah dengan mengamati nilai Variance Influaction Factor (VIF) dan Tolerance. Batas VIF adalah 10 dan nilai dari Tolerance adalah 0,1 . Jika nilai VIF lebih besar dari 10 dan nilai Tolerance kurang dari 0,1 maka terjadi multikolinearitas. Bila ada variabel independen yang terkena multikolinearitas maka variabel tersebut harus dikeluarkan dari model penelitian (Ghozali, 2001).

\section{Uji Heterokedastisitas}

Jika varian dari satu pengamatan ke pengamatan lain tetap, maka disebut homoskedostisitas atau tidak terjadi heterokedastisitas. Dan varian berbeda disebut heteroskedastisitas. Model regresi yang baik adalah yang homoskedostisitas atau tidak terjadi heterokedastisitas (Ghozali, 2001).

Untuk mengetahui ada atau tidaknya heterokedastisitas adalah dengan melihatgrafik plot antara nilai prediksi variabel terikat (ZPRED) dengan residualnya (SRESID).

\section{Uji Regresi}

Uji regresi berganda digunakan apabila jumlah variabel independen lebih dari satu variabel independen dan data variabel independen maupun dependen berupa interval. Tujuan menggunakan analisis regresi berganda untuk mengetahui beberapa variabel independen terhadap variabel 
dependen. Metode regresi berganda dirumuskan sebagai berikut:

$$
\mathrm{Y}=\mathrm{a}+b_{1} X_{1}+b_{2} X_{2}+b_{3} X_{3}+\mathrm{e}
$$

Keterangan:

Y : Keputusan Pembelian

a : Konstanta

b1 : Koefisien regresi $\mathrm{X}_{1}$

b2 : Koefisien regresi $\mathrm{X}_{1}$

b3 : Koefisien regresi $\mathrm{X}_{1}$

$\mathrm{X} 1$ : Pernyataan konsumen lewat internet (e WOM)

X2: Harga

X3: Kualitas Pelayanan

e : Error / variabel pengganggu / variabel residual

\section{Uji Hipotesis}

Uji t

Uji t dilakukan untuk mengetahui tingkat signifikan pengaruh variabel secara parsial dengan langkah-langkah sebagai berikut:

1. Merumuskan statistik hipotesis.

$\mathrm{H}_{0}: \mathrm{b} 1=0$, artinya suatu variabel bebas bukan merupakan penjelas yang signifikan terhadap variabel terukat. Berarti, variabel bebas $\mathrm{X}$ tidak mempengaruhi variabel terikat $Y$.

$\mathrm{H}_{0}: \quad b 1 \neq 0$, artinya variabel tersebut merupakan penjelas signifikan terhadap variabel dependen. Berarti variabel bebas $\mathrm{X}$ mempengaruhi variabel terikat $\mathrm{Y}$.

2. Menentukan nilai kritis

Dipilih level of significant $=5 \%$ atau confidence interval $=95 \%$

Derajat bebas $=\mathrm{n}-\mathrm{k}-1$

Membandingkan hasil perhitungan $t_{\text {hitung }}$ dengan $t_{\text {tabel }}$.

Menentukan daerah penerimaan dan penolakan. Bila $t_{\text {hitung }}(-)>t_{\text {tabel }}(+)$, maka $\mathrm{H}_{0}$ diterima dan $\mathrm{H}_{\mathrm{a}}$ ditolak. Bila $\mathrm{t}_{\text {hitung }}(-)<$ $\mathrm{t}_{\text {tabel }}(+)$, maka $\mathrm{H}_{0}$ ditolak dan $\mathrm{H}_{\mathrm{a}}$ diterima.

\section{Pengambilan keputusan}

Bila $t_{\text {hitung }}(-)>t_{\text {tabel }}(+)$, maka $H_{0}$ diterima dan $\mathrm{H}_{\mathrm{a}}$ ditolak, artinya pernyataan konsumen leat internet(eWoM), harga, dan kualitas pelayanan secara parsial berpengaruh signifikan terhadap keputusan pembelian pada konsumen $e$ commerce Blibli.com.

Bila $t_{\text {hitung }}(-)<t_{\text {tabel }}(+)$, maka $\mathrm{H}_{0}$ ditolak dan $\mathrm{H}_{\mathrm{a}}$ diterima, artinya pernyataan konsumen lewat internet (eWoM), harga, dan kualitas pelayanan secara parsial tidak berpengaruh signifikan terhadap keputusan pembelian pada konsumen e-commerce Blibli.com.

Uji F (Uji Secara Simultan)

Regresi linier berganda digunakan untuk membuktikan apakah variabel-variabel bebas secara simultan mempunyai pengaruh terhadap variabel-variabel dependen, maka dilakukan uji F. Uji $F$ dengan tujuan untuk menguji keseluruh-an variabel independen, yaitu: pernyataan konsumen lewat internet (eWoM), harga, dan kualitas pelayanan terhadap satu variabel terikat, yaitu keputusan pembelian.

Variabel bebas mempunyai dampak yang signifikan terhadap variabel terikat jika F hitung > $\mathrm{F}$ tabel, maka $\mathrm{H}_{0}$ di tolak dan $\mathrm{H}_{\mathrm{a}}$ diterima, berarti dengan menggunakan tingkat signifikan sebesar 0,05 jika nilai $F_{\text {hitung }}>F_{\text {tabel }}$ maka secara bersama-sama seluruh variabel bebas mempengaruhi variabel terikat. Jika nilai probabilitas lebih kecil daripada 0,05 (untuk tingkat signifikansi $=0,05$ ), maka variabel bebas secara bersama-sama berpengaruh terhadap variabel terikat. Sedangkan jika nilai probabilitas lebih besar daripada 0,05 maka variabel bebas secara serentak tidak berpengaruh terhadap variabel terikat.

Kemudian akan diketahui apakah hipotesis dalam penelitian ini secara bersama-sama ditolak atau diterima, adapun bentuk hipotesis secara simultan adalah:

$H_{0}: b_{1}=b_{2}=b_{3}=0$; pernyataan konsumen lewat internet (eWoM), harga, dan kualitas pelayanan secara bersama-sama tidak berpengaruh terhadap keputusan pembelian.

$\mathrm{H}_{\mathrm{a}}: \mathrm{b}_{1} \neq \mathrm{b}_{2} \neq \mathrm{b}_{3}=0$; keputusan konsumen lewat internet (e WOM), harga, dan kualitas pelayanan secara bersama-sama berpengaruh terhadap keputusan pembelian.

Analisis Koefisien Determinasi (Adjusted $R^{2}$ )

Untuk mengukur seberapa jauh kemampuan model dapat menjelaskan variasi variabel dependen. Pada pengujian hipotesis pertama koefisien determinasi dilihat dari besarnya nilai (Adjusted $\mathrm{R}^{2}$ ) untuk mengetahui variabel bebas yaitu pernyataan konsumen lewat internet (e WOM), harga dan kualitas pelayanan berpengaruhnya terhadap keputusan pembelian. Nilai (Adjusted $\mathrm{R}^{2}$ ) mempunyai interval antara 0 dan 1. Jika nilai (Adjusted $\mathrm{R}^{2}$ ) bernilai besar (mendeteksi 1) berarti variabel bebas dapat memberikan hampir semua informasi yang dibutuhkan untuk memprediksi variabel terikat. Jika (Adjusted R kuadrat) bernilai kecil berarti 
kemampuan variabel bebas dalam menjelaskan variabel terikat sangat terbatas. Secara umum koefisien determinasi untuk data silang (crosssection) relatif lebih rendah karena adanya variasi yang besar antara masing-masing pengamatan, sedangkan untuk data runtun waktu (time series) biasanya mempunyai nilai koefisien determinasi yang tinggi.

\section{PEMBAHASAN}

\section{Uji Intrumen Penelitian}

\section{Uji Validitas}

Kuesioner dikatakan tidak valid apabila pertanyaan pada kuesioner mampu untuk mengungkapkan sesuatu yang akan diukur oleh kuesioner tersebut. Instrumen dapat dikatakan valid bila nilai $r$ hitung lebih besar dari $r$ tabel sebaliknya instrument dianggap tidak valid apabila $r$ hitung lebih kecil dari $r$ tabel.

\begin{tabular}{|c|c|c|c|c|}
\hline Variabel & Pernyataan & $\begin{array}{c}\text { Pearson } \\
\text { Correlation }\end{array}$ & $r$ tabel & Keterangan \\
\hline Pernyataan & $\mathrm{X}_{1.1}$ & 0,828 & 0,195 & Valid \\
\hline konsumen & $\mathrm{X}_{1.2}$ & 0,798 & 0,195 & Valid \\
\hline lewat & $\mathrm{X}_{1.3}$ & 0,847 & 0,195 & Valid \\
\hline $\begin{array}{l}\text { internet }(e \\
W O M)\end{array}$ & $\mathrm{X}_{1.4}$ & 0,593 & 0,195 & Valid \\
\hline \multirow[t]{4}{*}{ Harga } & $\mathrm{X}_{2.1}$ & 0,843 & 0,195 & Valid \\
\hline & $\mathrm{X}_{2.2}$ & 0,824 & 0,195 & Valid \\
\hline & $\mathrm{X}_{2.3}$ & 0,717 & 0,195 & Valid \\
\hline & $\mathrm{X}_{2.4}$ & 0,772 & 0,195 & Valid \\
\hline \multirow{5}{*}{$\begin{array}{l}\text { Kualitas } \\
\text { pelayanan }\end{array}$} & $\mathrm{X}_{3.1}$ & 0,619 & 0,195 & Valid \\
\hline & $\mathrm{X}_{3.2}$ & 0,823 & 0,195 & Valid \\
\hline & $\mathrm{X}_{3.3}$ & 0,727 & 0,195 & Valid \\
\hline & $\mathrm{X}_{3.4}$ & 0,804 & 0,195 & Valid \\
\hline & $\mathrm{X}_{3.5}$ & 0,806 & 0,195 & Valid \\
\hline \multirow{6}{*}{$\begin{array}{l}\text { Keputusan } \\
\text { pembelian }\end{array}$} & $\mathrm{Y} 1$ & 0,830 & 0,195 & Valid \\
\hline & Y2 & 0,782 & 0,195 & Valid \\
\hline & Y3 & 0,895 & 0,195 & Valid \\
\hline & Y4 & 0,839 & 0,195 & Valid \\
\hline & Y5 & 0,782 & 0,195 & Valid \\
\hline & Y6 & 0,889 & 0,195 & Valid \\
\hline
\end{tabular}

Sumber: Data diolah

Berdasarkan Tabel 2 terlihat bahwa semua butir pernyataan yang mengukur variabel Pernyataan konsumen lewat internet (eWOM), harga, kualitas pelayanan dan keputusan pembelian, keseluruhan variabel pernyataan dinyatakan valid. Karena keseluruhan pernyataan mempunyai nilai $r$ hitung $>r$ tabel.

\section{Uji Reliabilitas}

Uji reabilitas dalam penelitian ini digunakan untuk mengukur sebuah kuisioner. Menurut Ghozali (2016) kuisioner dapat dikatakan reliabel bila jawabannya konsisten pada waktu ke waktu. Metode uji reliabilitas menggunakan yaitu metode Cronbach Alpha dengan bantuan program SPSS.
Suatu variabel dapat dikatakan reliabel bila memiliki nilai Cronbach Alpha lebih dari 0,700.

Tabel 2 Hasil Uji Reliabilitas

\begin{tabular}{lcc}
\hline \multicolumn{1}{c}{ Variabel } & $\begin{array}{c}\text { Cronbach } \\
\text { Alpha }\end{array}$ & Keterangan \\
\hline Electronic Word Of Mouth & 0,771 & Reliabel \\
Harga & 0,797 & Reliabel \\
Kualitas pelayanan & 0,815 & Reliabel \\
Keputusan pembelian & 0,911 & Reliabel \\
Sumber: diolah & &
\end{tabular}

Tabel 3.

Uji Regresi Berganda

\begin{tabular}{lrrrrrr}
\hline \multirow{2}{*}{ Model } & \multicolumn{2}{c}{$\begin{array}{l}\text { Unstandardized } \\
\text { Coefficients }\end{array}$} & \multicolumn{2}{c}{$\begin{array}{c}\text { Standardized } \\
\text { Coefficients }\end{array}$} & \multirow{2}{*}{ T } & \multirow{2}{*}{ Sig. } \\
\cline { 2 - 5 } & $\mathrm{B}$ & $\begin{array}{c}\text { Std. } \\
\text { Error }\end{array}$ & \multicolumn{2}{c}{ Beta } & & \\
\hline 1 & & & & & \\
\hline (Constant) & -1.035 & .489 & & -2.118 & .037 \\
\hline $\mathrm{X} 1$ & .548 & .108 & .466 & 5.098 & .000 \\
\hline $\mathrm{X} 2$ & .332 & .079 & .285 & 4.173 & .000 \\
\hline $\mathrm{X} 3$ & .358 & .118 & .270 & 3.020 & .003 \\
\hline
\end{tabular}

Sumber: Data diolah

Tabel 3 menunjukkan bahwa variabel dalam kuesioner ini reliabel karena mempunyai nilai Cronbach's alpha lebih besar dari 0,7.

Analisis Regresi Linier Berganda

Perhitungan regresi linier berganda antara Pernyataan konasumen lewat internet (eWOM), harga dan kualitas pelayanan terhadap keputusan pembelian dengan dibantu program SPSS 20.0 dalam proses perhitungannya dapat diperoleh hasil sebagai berikut:

$$
\mathrm{Y}=-1,035+0,548 \mathrm{X} 1+0,332 \mathrm{X} 2+0,358
$$

Hasil persamaan regresi linier berganda tersebut diatas memberikan pengertian bahwa: 1) Konstanta sebesar -1,035 menunjukkan bahwa jikapernyataan konsumen lewat internet (eWOM), harga dan kualitas pelayanan $=0$ atau tidak ada, maka keputusan pembelian akan sebesar -1,035. 2) Koefisien regresi untuk variabel pernyataan konsumen lewat internet (eWOM) sebesar 0,548. Koefisien positif menunjukkan bahwa variabel pernyataan konsumen lewat internet (eWOM) mempunyai hubungan searah dengan keputusan pembelian. Artinya apabila pernyataan konsumen lewat internet (eWOM) meningkat sebesar satusatuan akan diikuti dengan meningkatnya keputusan pembelian sebesar 0,548 dengan asumsi variabel bebas lain dalam keadaan konstan.

Koefisien regresi untuk variabel harga sebesar 0,332. Koefisien positif dimana variabel harga 
mempunyai hubungan searah dengan keputusan pembelian. Artinya apabila harga meningkat sebesar satu-satuan akan diikuti dengan meningkatnya keputusan pembelian sebesar 0,332 dengan asumsi variabel bebas lain dalam keadaan konstan.

Koefisien regresi untuk variabel kualitas pelayanan sebesar 0,358. Koefisien positif dimana variabel kualitas pelayanan mempunyai hubungan searah dengan keputusan pembelian. Artinya apabila kualitas pelayanan meningkat sebesar satu-satuan akan diikuti dengan meningkatnya keputusan pembelian sebesar 0,358 dengan asumsi variabel bebas lain dalam keadaan konstan.

\section{Uji Asumsi Klasik}

\section{Uji Normalitas}

Untuk menguji apakah variabel-variabel yang digunakan dalam model regresi mempunyai distribusi normal atau tidak. Pendekatan Kolmogorov Smirnov dan pendekatan grafik dapat digunakan untuk mengetahui data tersebut berdistribusi normal atau tidak. Hasil normalitas adalah sebagai berikut:

\section{Dependent Variable: Y}

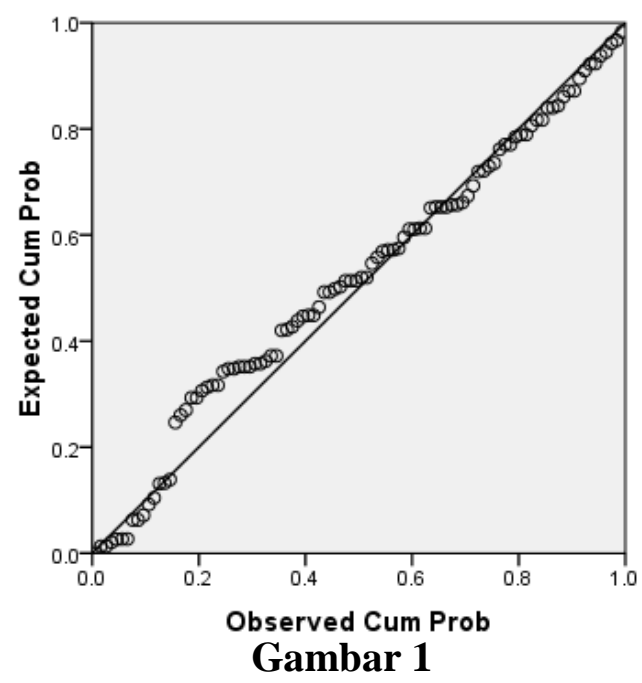

Uji Normalitas Menggunakan Grafik P-Plot

Sumber: data diolah

Tabel 4

Hasil Uji Normalitas

One-Sample Kolmogorov-Smirnov Test

Unstandardized Residual

\begin{tabular}{lc}
\hline Kolmogorov-Smirnov Z & 1.100 \\
\hline Asymp. Sig. (2-tailed) & .178 \\
\hline
\end{tabular}

a. Test distribution Norrmal

Sumber: diolah
Hasil grafik plot normal dapat diketahui berada di sepanjang garis $45^{\circ}$, sedangkan nilai signifikasi Kolmogorov-Smirnov pada Asymp. Signifikansi lebih besar dari $5 \%(0,05)$ yaitu sebesar 0,178 maka dapat disimpulkan bahwa data tersebut berdistribusi normal, sehingga dapat digunakan dalam penelitian.

Uji Multikolinieritas

Untuk mengetahui ada tidaknya multikolinieritas dalam model regresi yaitu menggunakan nilai tolerance dan variance inflation factor (VIF). Jika nilai tolerance $>0,01$ maka menunjukkan tidak terjadi multikolinieritas, jika nilai tolerance $<0,10$ menunjukkan terjadi multikolinieritas.

\section{Tabel 5}

Uji Multikolinieritas

\begin{tabular}{lccl}
\hline \multirow{2}{*}{ Variabel } & \multicolumn{2}{c}{ Collinearity Statistics } & \multirow{2}{*}{ Keterangan } \\
\cline { 2 - 3 } & Tolerance & VIF & \\
\hline $\begin{array}{l}\text { Electronic Word } \\
\text { Of Mouth }\end{array}$ & 0,509 & 1,966 & $\begin{array}{l}\text { Non } \\
\text { Multikolinearitas }\end{array}$ \\
\hline Harga & 0,915 & 1,096 & $\begin{array}{l}\text { Non } \\
\text { Multikolinearitas }\end{array}$ \\
\hline $\begin{array}{l}\text { Kualitas } \\
\text { pelayanan }\end{array}$ & 0,531 & 1,882 & $\begin{array}{l}\text { Non } \\
\text { Multikolinearitas }\end{array}$ \\
\hline
\end{tabular}

Sumber: Data primer yang diolah

Berdasarkan tabel 5 diatas terlihat bahwa nilai tolerance mendekati angka 1 dan nilai variance inflation factor (VIF) lebih rendah dari 10 untuk setiap variabel, maka hal ini berarti dalam persamaan regresi tidak ditemukan adanya korelasi antar variabel independen atau bebas multikolinieritas, sehingga seluruh variabel independen tersebut dapat digunakan dalam penelitian.

\section{Uji Heteroskedastisitas}

Terjadi heteroskedastisitas jika variance berbeda dan jika varians dari residual dari pengamatan ke pengamatan pengamatan lain tetap terjadi homoskedastisitas.

Berdasarkan gambar 2 grafik scatterplot menunjukkan bahwa data tersebar disekitar angka 0 (nol) pada garis Y dan tidak terdapat suatu pola yang jelas pada penyebaran data tersebut. Berarti pada model persamaan regresi tidak terjadi heteroskedastisitas, sehingga model regresi dapat digunakan untuk memprediksi keputusan pembelian berdasarkan variabel-variabel yang mempengaruhinya yaitu pernyataan konsumen lewat internet (Electronic Word Of Mouth), harga dan kualitas pelayanan. Maka model persamaan 
regresi linier bebas dari asumsi dasar (klasik) tersebut, sehingga pengambilan keputusan melalui uji $\mathrm{F}$ dan uji $\mathrm{t}$ yang akan dilakukan dalam penelitian ini tidak akan bias atau sesuai dengan tujuan penelitian.

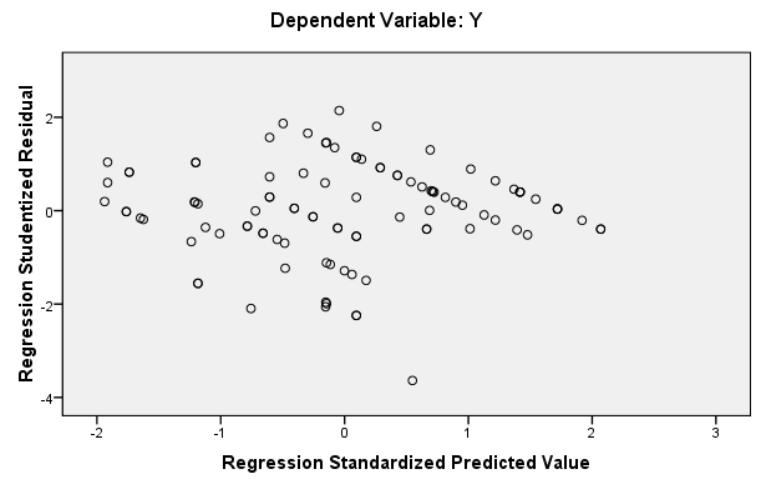

Gambar 2

Hasil Pengujian Heteroskedastisitas Menggunakan Scatterplot

Sumber: data diolah

Tabel 6

Hasil Uji Koefisien Determinasi \& Koefisien Korelasi Berganda

\begin{tabular}{|c|c|c|c|c|}
\hline \multirow{3}{*}{$\begin{array}{c}\text { Model } \\
1\end{array}$} & \multirow{3}{*}{$\begin{array}{l}\mathrm{R} \\
769\end{array}$} & & \multicolumn{2}{|c|}{ Adjusted R $\quad$ Std. Error of The } \\
\hline & & R.Square & Square & Estimate \\
\hline & & 0,592 & .579 & 3.9931 \\
\hline
\end{tabular}

Sumber: Data diolah

\section{Uji Kelayakan Model}

Uji Koefisien Determinasi $\left(\mathrm{R}^{2}\right)$

Tabel 6 menunjukkan nilai R sebesar 0,769.

Hal ini berarti bahwa hubungan atau korelasi antara faktor-faktor yang mempengaruhi keputusan pembelian adalah cukup kuat karena > 0,50 . Nilai $R$ Square sebesar 0,592 atau $59,2 \%$, ini menunjukkan bahwa variabel keputusan pembelian yang dapat dijelaskan variabel pernyataan konsumen lewat internet (Electronic Word Of Mouth), harga dan kualitas pelayanan dalah sebesar 59,2\%, sedangkan sisanya 40,8\% dijelaskan faktor-faktor lain yang tidak disertakan dalam model penelitian ini.
Uji Statistik F

Pengujian ini dilakukan untuk mengetahui apakah pernyataan konsumen lewat internet (Electronic Word Of Mouth), harga dan kualitas pelayanan berpengaruh terhadap keputusan pembelian. Hasil pengujian ini dapat dilihat pada Tabel 7.

Dari Tabel 7 dapat dilihat bahwa nilai $F_{\text {hitung }}$ dengan tingkat signifikansi 0,000 (di bawah $0,05)$. Berdasarkan tingkat signifikansinya, maka disimpulkan bahwa variabel yang terdiri dari pernyataan konsumen lewat internet (e-WOM), harga dan kualitas pelayanan mempunyai pengaruh signifikan terhadap keputusan pembelian. Sehingga model penelitian yang diajukan sudah fit.

\section{Tabel 7}

Uji F

\begin{tabular}{clccccc}
\hline Model & & Sum of Square & Df & Mean Square & F & Sig. \\
\hline \multirow{2}{*}{1} & Regression & 22.190 & 3 & 7.397 & 46390 & 0.000 \\
& Residual & 15.307 & 96 & .159 & & \\
\hline \multicolumn{2}{r}{ Total } & 37.497 & 99 & & & \\
\hline
\end{tabular}

a. Predictor: (Constant), X3, X2, X1

b. Dependent Variable: Y

Sumber: Data diolah 


\section{Tabel 8}

Hasil Uji t

\section{Coefficients}

\begin{tabular}{|c|c|c|c|c|c|c|c|}
\hline \multirow[b]{2}{*}{ Model } & \multicolumn{2}{|c|}{$\begin{array}{l}\text { Unstandardized } \\
\text { Coefficients }\end{array}$} & \multirow{2}{*}{$\begin{array}{c}\text { Standardized } \\
\text { Coefficients } \\
\text { Beta }\end{array}$} & \multirow[b]{2}{*}{$\mathrm{T}$} & \multirow[b]{2}{*}{ Sig. } & \multicolumn{2}{|c|}{$\begin{array}{l}\text { Collinearity } \\
\text { Statistics }\end{array}$} \\
\hline & B & Std. Error & & & & Tolerance & VIF \\
\hline 1 (Constant) & -1.035 & .489 & & -2.118 & .037 & & \\
\hline $\begin{array}{l}\text { Pernyataan Konsumen lewat } \\
\text { internet (e WOM) }\end{array}$ & .548 & .108 & .466 & 5.098 & .000 & .509 & 1.966 \\
\hline Harga & .332 & .079 & .245 & 2.173 & .060 & .915 & 1.093 \\
\hline Kualitas Pelayanan & .358 & .118 & .270 & 3.020 & .003 & .531 & 1.882 \\
\hline
\end{tabular}

a. Dependent Variable: Keputusan Pembelian

Sumber: Data primer yang diolah

\section{Pengujian Hipotesis}

Berdasarkan perhitungan uji regresi berganda yang tercantum pada Tabel 8, maka hasilnya memberikan pengertian bahwa:

Berdasarkan hasil perhitungan Tabel 8, diperoleh nilai koefisien regresi bernilai positif dan nilai signifikasi untuk pernyataan konsumen lewat internet (eWoM) adalah $\alpha=0,000<0,05$ menandakan bahwa pernyataan konsumenn lewat internet (eWoM) mempunyai pengaruh signifikan terhadap keputusan pembelian. Sehingga $\mathrm{H}_{1}$ yang menyatakan dugaan adanya pengaruh pernyataan konsumen lewat internet (eWoM) terhadap keputusan pembelian diterima.

Hasil perhitungan Tabel 8, diperoleh nilai koefisien regresi bernilai positif dan nilai signifikasi untuk harga adalah $\alpha=0,060>0,05$ menandakan bahwa harga mempunyai pengaruh tidak signifikan terhadap keputusan pembelian. Sehingga $\mathrm{H}_{2}$ yang menyatakan dugaan adanya pengaruh harga terhadap keputusan pembelian tidak diterima.

Hasil perhitungan Tabel 8 , diperoleh nilai koefisien regresi bernilai positif dan nilai signifikasi untuk kualitas pelayanan adalah $\alpha=$ $0,003<0,05$ menandakan bahwa kualitas pelayanan mempunyai pengaruh signifikan terhadap keputusan pembelian

\section{PEMBAHASAN}

\section{Pernyataan konsumen lewat internet (Electronic Word of Mouth) Terhadap Keputusan Pembelian}

Pernyataan konsumen lewat internet (Electronic Word Of Mouth) berpengaruh yang signifikan terhadap keputusan pembelian, hal ini dibuktikan dengan nilai signifikan sebesar 0,000 lebih kecil dari 0,05. Sehingga hal ini berarti bahwa variabel Electronic Word Of Mouth berpengaruh signifikan terhadap keputusan pembelian. Jika pernyataan konsumen lewat internet (Electronic Word Of Mouth) ditingkatkan maka keputusan pembelian meningkat. Hasil ini Sesuai dengan penelitian yang dilakukan Sari, Saputra, dan Husein (2017) bahwa electronic word of mouth berpengaruh secara positif dan signifikan terhadap keputusan pembelian. Hal ini diperkuat juga dalam penelitian Nurrohman (2018) yang memperoleh hasil bahwa electronic word of mouth berpengaruh secara positif dan signifikan terhadap keputusan pembelian.

\section{Harga Terhadap Keputusan Pembelian}

Harga berpengaruh signifikan terhadap keputusan pembelian, hal ini dibuktikan dengan nilai signifikasi sebesar 0,060 lebih besar dari 0,05. Sehingga dapat dikatakan bahwa variabel harga berpengaruh tidak signifikan terhadap keputusan pembelian. Jika harga turun maka keputusan pembelian akan meningkat. Sesuai yang dilakukan oleh Nurrohman (2018) bahwa harga berpengaruh secara negatif dan signifikan terhadap keputusan pembelian. Hal ini diperkuat juga dalam penelitian Armahadyani (2017) yang memperoleh hasil bahwa harga berpengaruh secara negatif dan signifikan terhadap keputusan pembelian.

Harga sebuah produk dan jasa merupakan faktor penentu utama permintaan pasar, harga merupakan sebagai jumlah uang (ditambah beberapa produk) yang dibutuhkan untuk mendapatkan sejumlah kombinasi dari produk dan pelayanannya. Penetapan harga merupakan hal yang paling sulit diantara unsur-unsur dalam bauran pemasaran. Menurut Alma (2007) Harga merupakan suatu nilai yang dinyatakan dengan uang. Harga sangat menentukan seorang konsumen dalam melakukan pembelian, seperti yang diungkapkan oleh Tjiptono (2008) yang 
menyatakan bahwa fungsi harga adalah membantu para pembeli untuk memutuskan cara memperoleh manfaat tertinggi yang diharapkan berdasarkan daya belinya.

\section{Pengaruh Kualitas pelayanan Terhadap Keputusan pembelian}

Kualitas pelayanan mempunyai pengaruh yang signifikan terhadap keputusan pembelian, hal ini dibuktikan dengan nilai signifikasi sebesar 0,003 lebih kecil dari 0,05 . Sehingga dapat dikatakan bahwa variabel kualitas pelayanan berpengaruh signifikan terhadap keputusan pembelian. Jika kualitas pelayanan ditingkatkan maka keputusan pembelian akan meningkat juga.

Hasil penelitian ini sesuai dengan penelitian Dewi dkk (2017) bahwa kualitas pelayanan berpengaruh secara positif dan signifikan terhadap keputusan pembelian. Persaingan yang semakin ketat akhirakhir ini menuntut sebuah lembaga penyedia jasa/layanan untuk selalu memanjakan konsumen/peelanggan dengan memberikan pelayanan terbaik. Para konsumen akan mencari produk berupa barang atau jasa dari perusahaan yang dapat memberikan pelayanan yang terbaik kepadanya (Assauri, 2003). Kualitas pelayanan adalah hal paling penting yang harus diperhatikan oleh perusahaan, karena kepuasan dan keputusan pembelian pada pelanggan sangat dipengaruhi oleh kualitas layanan yang baik (Qin \& Prybutok, 2009).

\section{PENUTUP}

\section{Simpulan}

1. Hasil uji $t$ dapat diketahui bahwa variabel pernyataan konsumen lewat internet (Electronic Word Of Mouth) mempunyai pengaruh yang signifikan terhadap keputusan pembelian, hal ini terbukti dengan nilai signifikansi untuk variabel tersebut.

2. Hasil uji t dapat diketahui bahwa variabel harga mempunyai pengaruh yang signifikan terhadap keputusan pembelian, hal ini terbukti dengan nilai signifikansi untuk variabel tersebut.

3. Berdasarkan hasil uji $\mathrm{t}$ dapat diketahui bahwa variabel kualitas pelayanan mempunyai pengaruh yang signifikan terhadap keputusan pembelian, hal ini terbukti dengan nilai signifikansi untuk variabel tersebut.

\section{Saran}

Bagi perusahaan:

1. Hasil penelitian menyatakan bahwa pernyataan konsumen lewat internet ( $e$ WOM) berpengaruh signifikan terhadap keputusan pembelian. Hal ini membuktikan bahwa sebaiknya perusahaan Blibli.com harus melakukan pengiklanan baik dari internet maupun dari media cetak agar konsumen dapat mengetahui tentang Blibli.com yang menjual berbagai macam produk atau barang yang dibutuhkan.

2. Hasil penelitian menyatakan bahwa variabel harga berpengaruh tidak signifikan terhadap keputusan pembelian. Hal ini membuktikan bahwa sebaiknya perusahaan Blibli.com meningkatkan pemberian potongan harga pada acara tertentu atau pada saat flash shop/flash sale agar konsumen semakin tertarik untuk melakukan pembelian.

Hasil penelitian menyatakan bahwa variabel kualitas pelayanan berpengaruh signifikan terhadap keputusan pembelian. Hal ini membuktikan bahwa sebaiknya perusahaan dapat menginformasikan kepada konsumen tentang kantor Blibli.com yang ada disetiap kota agar konsumen dapat dengan mudah menyampaikan keluhan atas pelayanannya agar konsumen semakin percaya terhadap Blibli.com.

Bagi peneliti selanjutnya:

1. Penelitian selanjutnya dapat memperbaiki keterbatasan yang ada dalam penelitian ini dan memperbanyak jumlah sampel dan cara pengambilan data untuk mendapatkan hasil yang menyeluruh.

2. Disarankan untuk melakukan penelitian di luar variabel bebas yang digunakan dalam penelitian ini, misalnya atribut produk, bauran pemasaran, yang dapat digunakan untuk meningkatkan keputusan pembelian, mengingat terdapat pengaruh sebesar $40,8 \%$ dari variabel lain yang tidak ikut sertakan dalam penelitian ini.

\section{Keterbatasan}

Keterbatasan peneliti dalam penelitian ini adalah peneliti hanya meneliti pernyataan konsumen lewat internet (eWOM), harga dan kualitas pelayanan terhadap keputusan konsumen. Dengan demikian perlu digali variabel lain yang dapat mempengaruhi keputusan pembelian, seperti atribut produk, bauran pemasaran dan promosi yang dapat digunakan untuk meningkatkan keputusan pembelian.

\section{DAFTAR PUSTAKA}

Alma, Buchari. (2007). Manajemen Pemasaran \& Pemasaran Jasa. Bandung: CV. Alfabeta. 
Armahadyani. (2017). Pengaruh Harga, Promosi, dan Kualitas Pelayanan Terhadap Keputusan Pembelian Konsumen Pada Kedai Makan Pa'Mur Karawang. Jurnal Universitas Singaperbangsa Karawang.

Assauri, Sofyan. 2003. Manajemen Pemasaran, Jilid 1. Jakarta: PT. Gramedia Pustaka Utama.

Bashar, Abu, et al. 2012. Effectiveness of Social Media as a Marketing Tool : an Empirical Study. International Journal of Marketing; 11(1): 88-99

Bhuno, Agung Nugroho. (2005). Strategi Jitu "Memilih Metode Statistik Penelitian dengen SPSS". Yogyakarta : Andi Offset.

Dewi, R.Y., Yulianeu, Haryono, A.T., Gagah, E. (2017). Pengaruh Kepercayaan Konsumen, Kemudahan dan Kualitas Informasi Terhadap Keputusan Pembelian Secara Online dengan Minat Beli Sebagai Variabel Intervening (Studi pada Pengguna Situs Jual Beli Bukalapak.com). Journal of Management, Vol. 3, No. 3

Ghozali, Imam. (2001). Aplikasi Analisis Multivariate Dengan Program SPSS. Semarang: Badan Peneliti Universitas Diponegoro.

Ghozali, Imam. (2002). Statistik Non-Parametrik Teori dan Aplikasi dengan Program SPSS. Semarang: Badan Penerbit Universitas Diponegoro.

Ghozali, Imam. (2016). Aplikasi Analisis Multivariete Dengan Program IBM SPSS 23 (Edisi 8). Cetakan ke VIII. Semarang: Badan Penerbit Universitas Diponegoro.

Henning-Thurau, T; Gwinner, K. P; Walsh, G; and Gremler, D. D., 2004. Electronic Word-OfMouth Via Consumer-Opinion Platforms: What Motivates Consumers to Articulate Themselves on the Internet?, Wiley Periodcals, INC., 18, 38-52.
Kotler, Philip. dan Armstrong, Gary. (2012). Prinsip-Prinsip Pemasaran. Edisi 13. Jilid 1. Erlangga: Jakarta.

Kotler, Philip. 2009. Manajemen Pemasaran (Marketing Management) (Edisi 13). U.S.A: Pearson Prentice Hall.

Laheba, Yitzhak Armando, Tumbuan, W. J. F, Soepono, Djurwati. (2015). Pengaruh Citra Merek, Fitur dan Harga terhadap Keputusan Pembelian Handphone Samsung (Studi pada Mahasiswa FEB Unsrat Manado), Jurnal EMBA, Vol3, No.3 Hal 99-108.

Laudon, Kenneth C. dan Laudon, Jane P. (2007) Sistem Informasi Manajemen. Edisi ke-10. Terjemahan Chriswan Sungkono dan Machmudin Eka P. Jakarta: Salemba Empat

Nurrohman, Faris. (2018). Pengaruh Electronic Word Of Mouth, Harga, Dan Kualitas Produk Terhadap Keputusan Pembelian (Studi Kasus pada Smartphone Merek Blackberry di Yogyakarta). Thesis, Fakultas Ekonomi. Universitas Negeri Yogyakarta

Qin, Hong \& Prybutok, Victor R. 2009. Service Quality, Customer Satisfaction, and Behavioral Intentions in Fast-Food Restaurants. International Journal of Quality and Service Sciences, 1 (1), (78-95).

Sari, Novita. Saputra, Muhammad. dan Husein, Jamaluddin. (2017). Pengaruh Electronic Word Of Mouth Terhadap Keputusan Pembelian Pada Toko Online Bukalapak.com. Jurnal Manajemen Magister Darmajaya, Vol 3, No. 01.

Sugiyono. (2004). Metode Penelitian. Bandung: Alfabeta.

Sugiyono. (2009). Metode Penelitian Kuantitatif, Kualitatif dan $R \& D$. Bandung: Alfabeta.

Sutedja, Wira. (2007). Panduan Layanan Konsumen. Jakarta: PT. Grasindo

Tjiptono, Fandy. (2008). Strategi Pemasaran. Edisi Ketiga. Andi, Yogyakarta 